Editorial

\title{
Fuzzy Techniques for Decision Making
}

\author{
José Carlos R. Alcantud
}

BORDA Research Unit and IME, University of Salamanca, 37008 Salamanca, Spain; jcr@usal.es

Received: 22 December 2017; Accepted: 25 December 2017; Published: 27 December 2017

This book contains the successful invited submissions [1-21] to a Special Issue of Symmetry on the subject area of "Fuzzy Techniques for Decision Making".

We invited contributions addressing novel techniques and tools for decision making (e.g., group or multi-criteria decision making), with notions that overcome the problem of finding the membership degree of each element in Zadeh's original model. We could garner interesting articles in a variety of setups, as well as applications. As a result, this Special Issue includes some novel techniques and tools for decision making, such as:

- Instrumental tools for analysis like correlation coefficients [1,16] or similarity measures [4] and aggregation operators $[2,21]$ in various settings.

- Novel contributions to methodologies, like discrete optimization with fuzzy constraints [3], COMET [5], or fuzzy bi-matrix games [7].

- New methodologies for hybrid models [12,15,18,20] inclusive of theoretical novelties [9].

- Applications to project delivery systems [6], maintenance performance in industry [8], group emergencies [10], pedestrians flows [11], valuation of assets [13], water pollution control [17], or aquaculture enterprise sustainability [19].

- A comparative study of some classes of soft rough sets [14].

Response to our call had the following statistics:

- $\quad$ Submissions (58);

- Publications (21);

- $\quad$ Rejections (37);

- $\quad$ Article types: Research Article (21);

Authors' geographical distribution (published papers) is:

- China (11)

- Spain (4)

- Pakistan (2)

- Poland (1)

- Japan (1)

- Taiwan (1)

- $\quad$ Slovenia (1)

Published submissions are related to various settings like fuzzy soft sets, hesitant fuzzy sets, (fuzzy) soft rough sets, neutrosophic sets, as well as other hybrid models.

I found the edition and selections of papers for this book very inspiring and rewarding. I also thank the editorial staff and reviewers for their efforts and help during the process. 
Conflicts of Interest: The authors declare no conflict of interest.

\section{References}

1. Ye, J. Multiple Attribute Decision-Making Method Using Correlation Coefficients of Normal Neutrosophic Sets. Symmetry 2017, 9, 80. [CrossRef]

2. Chen, J.; Ye, J. Some Single-Valued Neutrosophic Dombi Weighted Aggregation Operators for Multiple Attribute Decision-Making. Symmetry 2017, 9, 82. [CrossRef]

3. Jelušič, P.; Žlender, B. Discrete Optimization with Fuzzy Constraints. Symmetry 2017, 9, 87. [CrossRef]

4. Jiang, W.; Shou, Y. A Novel Single-Valued Neutrosophic Set Similarity Measure and Its Application in Multicriteria Decision-Making. Symmetry 2017, 9, 127. [CrossRef]

5. Faizi, S.; Sałabun, W.; Rashid, T.; Watróbski, J.; Zafar, S. Group Decision-Making for Hesitant Fuzzy Sets Based on Characteristic Objects Method. Symmetry 2017, 9, 136. [CrossRef]

6. Luo, S.; Cheng, P.; Wang, J.; Huang, Y. Selecting Project Delivery Systems Based on Simplified Neutrosophic Linguistic Preference Relations. Symmetry 2017, 9, 151. [CrossRef]

7. Zhang, W.; Xing, Y.; Qiu, D. Multi-objective Fuzzy Bi-matrix Game Model: A Multicriteria Non-Linear Programming Approach. Symmetry 2017, 9, 159. [CrossRef]

8. Carnero, M. Asymmetries in the Maintenance Performance of Spanish Industries before and after the Recession. Symmetry 2017, 9, 166. [CrossRef]

9. Tang, H. Decomposition and Intersection of Two Fuzzy Numbers for Fuzzy Preference Relations. Symmetry 2017, 9, 228. [CrossRef]

10. Wang, L.; Labella, Á.; Rodríguez, R.; Wang, Y.; Martínez, L. Managing Non-Homogeneous Information and Experts' Psychological Behavior in Group Emergency Decision Making. Symmetry 2017, 9, 234. [CrossRef]

11. Xue, Z.; Dong, Q.; Fan, X.; Jin, Q.; Jian, H.; Liu, J. Fuzzy Logic-Based Model That Incorporates Personality Traits for Heterogeneous Pedestrians. Symmetry 2017, 9, 239. [CrossRef]

12. Liu, Z.; Qin, K.; Pei, Z. A Method for Fuzzy Soft Sets in Decision-Making Based on an Ideal Solution. Symmetry 2017, 9, 246. [CrossRef]

13. Alcantud, J.; Rambaud, S.; Torrecillas, M. Valuation Fuzzy Soft Sets: A Flexible Fuzzy Soft Set Based Decision Making Procedure for the Valuation of Assets. Symmetry 2017, 9, 253. [CrossRef]

14. Liu, Y.; Martínez, L.; Qin, K. A Comparative Study of Some Soft Rough Sets. Symmetry 2017, 9, 252. [CrossRef]

15. Katagiri, H.; Kato, K.; Uno, T. Possibility/Necessity-Based Probabilistic Expectation Models for Linear Programming Problems with Discrete Fuzzy Random Variables. Symmetry 2017, 9, 254. [CrossRef]

16. Wang, Z.; Li, J. Correlation Coefficients of Probabilistic Hesitant Fuzzy Elements and Their Applications to Evaluation of the Alternatives. Symmetry 2017, 9, 259. [CrossRef]

17. Liu, J.; Li, Y.; Huang, G.; Chen, L. A Recourse-Based Type-2 Fuzzy Programming Method for Water Pollution Control under Uncertainty. Symmetry 2017, 9, 265. [CrossRef]

18. Akram, M.; Ali, G.; Alshehri, N. A New Multi-Attribute Decision-Making Method Based on m-Polar Fuzzy Soft Rough Sets. Symmetry 2017, 9, 271. [CrossRef]

19. Wu, T.; Chen, C.; Mao, N.; Lu, S. Fishmeal Supplier Evaluation and Selection for Aquaculture Enterprise Sustainability with a Fuzzy MCDM Approach. Symmetry 2017, 9, 286. [CrossRef]

20. Sarwar, M.; Akram, M. New Applications of m-Polar Fuzzy Matroids. Symmetry 2017, 9, 319. [CrossRef]

21. Kobina, A.; Liang, D.; He, X. Probabilistic Linguistic Power Aggregation Operators for Multi-criteria Group Decision Making. Symmetry 2017, 9, 320. [CrossRef]

(c) 2017 by the author. Licensee MDPI, Basel, Switzerland. This article is an open access article distributed under the terms and conditions of the Creative Commons Attribution (CC BY) license (http://creativecommons.org/licenses/by/4.0/). 